\title{
N'zassa: from a collaborative translation approach to a collective construct
}

\begin{abstract}
The ethnographic approach to literary translation offers, undoubtedly, many avenues yet to be explored. If we can consider translation to be a perpetual search for a possibility, dialogic translation consists of waging with the 'other'-be they present physically and/or metaphysically-the battle for meaning. The n'zassa approach has no aim but to both reinforce the translator's visibility and build a trustworthy relationship with (trans)readers. I argue that every translation act is-or should be-based, to some extent, on a n'rassa approach, which sees translation practice as a collaborative activity, and its product, a collective construct wherein writers, translators and readers are Meaning Weavers. Each text carries an embryo of such an encounter, which stems from and results in mutual influences. With regard to the relation ethnography-translation, Buzelin (2004, 2005), Ferreira (2014, 2017 ) and Wolf's (2000) discussions prove fundamental. I conclude that Adiaffi's n'rassa, read through the lens of Latour's (2008) ANT, helps reduce information lost and gives the translator a type of immediate collective acceptance. It is only through dialogue between subjects and forms, between divergent and convergent choices in the practice of translation that one can strive for a real and inclusive knowledge economy.
\end{abstract}

Keywords: $n^{\prime}$ zassa, collaborative translation, collective construct, dialogism, ethnographic approach.

\section{N'zassa: de l'approche collaborative à la traduction vers une construction collective}

\section{Résumé}

L'approche ethnographique à la traduction offre, sans aucun doute, de nombreuses pistes à explorer. Si l'on considère la traduction comme une perpétuelle quête de possibilité, la traduction dialogique consiste donc à engager avec l'autre - puisse celui-ci être présent physiquement et/ou métaphysiquement - la bataille du sens. L'approche n'zassa vise non seulement à renforcer la visibilité du traducteur mais à construire une relation de confiance avec les translecteurs. Je défends que tout acte traductif est - ou devrait être - à certains égards, mené à partir d'une approche n'zassa qui voit en la pratique traductive une activité collaborative et son produit, une construction collective à laquelle les écrivains, les traducteurs et les lecteurs prennent part en tant que tisseurs de sens. Chaque texte porte ainsi un fœetus de cette rencontre qui découle et se somme par des influences mutuelles. Pour ce qui concerne la relation ethnographie-traduction, les travaux de Buzelin (2004, 2005), Ferreira $(2014,2017)$ et ceux de Wolf (2000) ont été fondamentaux. Je conclus que le n'zassa adiaffien lu à travers le prisme de la TAR permet de réduire la perte d'informations permettant au traducteur de jouir d'une forme d'acceptation collective spontanée. Ce n'est qu'à travers le dialogue entre sujets et formes, entre choix divergents et/ou convergents opérés au cours du processus de traduction que l'on peut espérer une économie de savoir réelle et inclusive.

Mots-clés: n'₹assa, traduction collaborative, construction collective, dialogisme, approche ethnographique. 


\section{N'zassa: De un enfoque de traducción colaborativa a una construcción colectiva}

Resumen

Sin duda, el enfoque etnográfico en la traducción literaria ofrece muchas posibilidades inexploradas. Si se considera a la traducción una búsqueda perpetua de posibilidad, la traducción dialógica consiste en librar contra el otro -sea su presencia física o metafísica- la batalla por el sentido. El enfoque n'zassa busca tanto reforzar la visibilidad del traductor como construir una relación de confianza con los (trans)lectores. Defiendo que todo acto traductivo está - o debería estar-basado en cierta medida en un enfoque n'zassa, que ve en la traducción una actividad colaborativa y en su producto una construcción colectiva, en la que los escritores, traductores y lectores son tejedores de sentido. Sobre la relación entre etnografía y traducción, los trabajos de Buzelin (2004, 2005), Ferreira $(2014,2017)$ y Wolf (2010) son fundamentales. Concluyo que la lectura del n'zassa adiaffiano, desde la perspectiva de la teoría del actor-red de Latour, ayuda a reducir la pérdida de información y le otorga al traductor una especie de aceptación colectiva inmediata. Solo a través del diálogo entre sujetos y formas, y entre decisiones divergentes o convergentes en la práctica traductiva, se puede esperar una economía real e inclusiva del conocimiento.

Palabras clave: n'zassa, traducción colaborativa, construcción colectiva, dialogismo, enfoque etnográfico 


\section{Introduction}

Objectivity, Latour (2008) explains, is on the other side of the border out of reach. If so, one may consider that any reading (interpretation) of a moving prose (daily life in a specific society) or, of a fixed prose (the written narratives of that same society) undoubtedly produces an individual objectivity which builds on that individual's subjective vision of the fleeting world being portrayed. The identification and interpretation of the real in that infinite realm is, for every translator, a true challenge. In the building of what Bandia (2000) called a "comprehensive history of Translation Studies," ethnographic considerations play a key role. More specifically, in attempting to bring one culture into another for the sake of pluralism, the focal point will always be that of understanding the societies involved and knowing their customs, structures and functions, and the elements that contribute to their peculiarities. These elements can be inscribed into the language (or into the way it is utilized), into clothing, into names and the naming process, or into its oral literature (songs, poetry, proverbs, riddles, philosophy, etc.). All of them partake in the shaping and conveying of a vision. In literary translation of written works in general, one assumes that a translator investigates these elements. Indeed, Buzelin (2005) is right when she says that both theoretical approaches (descriptive and polysystem studies) contributed a lot to the debate in the field of translation, and yet a "process-oriented kind of research is needed." It is in this search of a practical stance that the n'zassa concept enters the debate about translation practice. I am attempting here to give the Actor-Network concept another direction, or to show some of its analogies with the n'zassa. In fact, what I am proposing is a translation culture.

This paper is structured as follows: first, it provides a brief definition of both concepts: n'zassa and Actor-Network Theory (ANT), and attempts to outline their convergent and divergent points. Then, it focuses on the contribution of n'zassa, drawing parallels with the debate on a dialogic approach to translation. In the last two sections, it discusses the knowledge economy and brings in a case study (the translation of The identity card [1983] to Brazilian Portuguese) where the idea of a collective construct takes form.

\section{N'zassa / Actor-Network: confluences}

The concept of n'zassa was born among the Anyi women in Côte d'Ivoire. It is said that, in the past, when a woman acquired woven fabric for clothes making, she would carefully keep a patch of it. The more fabric remnants a woman possessed, the more clothes one assumed she had, therefore the more respect and status she would get from society. Her fortune depended on the number of pieces she had. As time went on, it became trendy to assemble those fabric remnants to build a patchwork (see Bra, 2016) of multiple colors: a multifabric fabric named n'zassa. The concept was later introduced into literature by the Ivorian writer Jean-Marie Adiaffi. Adiaffi, in his early literary activities, based his writing on that philosophy. According to the very nature of n'zassa, Adiaffi would mingle different writing genres (prose, poetry, play, recital, proverbs, etc.) according to his inspiration. In other words, it is a mix of genres or "a genre without genre" (Tro Deho, 2009; Akohoue, 2013) whose specificity resides in the structure of the utterance, the narrow link between characters' languages and the vision of the society they live in. The discursive n'zassa encompasses at least two linguistic systems, that is, a canorous interpenetration of two languages (Bra, 2017). This systematic assembling which Adiaffi offered through both a linguistic creation and a combination of grammatical (dis)order may 
not be familiar to all the members of the interpretative community (or horizon of expectation). Consequently, the nature of such a "source-text" becomes difficult to determine. One can be exposed to a multiple-text ${ }^{1}$ which might lead to a multiple target text that also requires multiple hands. In a nutshell, a collective work. But how does the n'zassa concept help perceive the translated text as a shared and socially handmade product? The idea of collective target text translation could be described as a metaphorical "sauce," in which every ingredient contributes to the construction of the flavor. Note that loans in such a translated text, like ingredients in a sauce, are naturalized, while linguistic interferences are a conscious exercise. It also means that parties (subjects and/or objects) can question and be questioned in the process by which they reveal one another. Is this not the kind of liberty to which Latour's (2008) Actor-Network Theory referred? We shall see.

In the introduction of The scandals of Translation (1999), Lawrence Venuti wrote:

\begin{abstract}
The only prestige that a translator can gain comes from practicing translation, not as a form of personal expression, but as a collaboration between divergent groups, motivated by an acknowledgement of the linguistic and cultural differences that translation necessarily rewrites and reorders (Venuti, 1999, p. 4).
\end{abstract}

It is clear from this quote that translation reaches a dimension that makes it not an isolated individual work, but that of a community (like in Gender Studies) or a national affair (see, among others, Post-Colonial literary works in Africa, India, and Latin America). From Venuti's quote, one deduces that translators' glory resides in them having the opportunity of collaborating with peers in the

1 Though I consider it an open-ended notion. building of a common meaning string of an original perched on the wall of interpretation(s). This new "original," towards which each member lays the groundwork, conveys specific cultural or social realities to a public the participants are a priori acquainted with. That idea itself brings together the notions of "multiculturalism" and "hybridity," with the former producing the latter. Notwithstanding the ambiguity of the notion of multiculturalism, it is clear that "the other" cannot be denied its status of timely excepted entity. Even so, Wolf understands that multiculturalism "does not transcend the dialectic of inclusion and exclusion" (2000, pp. 141-142), at least, the way it is manifested within the translated text bears some resemblance to hybridity. I am therefore fully aware that, depending on how one approaches them, the distance between these two notions may be huge and their connections far smaller. However, I suggest we consider hybridity to be a fine and condensed articulation of the social and cultural particles expressed in, or represented by, the term multiculturalism, wherein "the celebrated other" is brought on stage in their exceptional otherness. In a hybrid State (or object), the other's identity may oscillate between the other-self (the other identity) and a self-other. If a complete merging rarely occurs, there is no doubt that both multiculturalism and hybridity tend to lionize an otherness on which their very existence depends. As far as African literature is concerned, any combination of the two notions may not be aimed at anything better than "inclusion." It is worth stressing that the African writer's literary works are not always a personal expression, but rather a condensed set of collective expressions performed by an individual. Therefore, as we draw on what Venuti said (see above), it should be no surprise that for its decoding, individuals be required or involved. It is following this logic that Latour's ANT may provide some insight. 
Reflecting upon how Bruno Latour's (2005, 2008) Actor-Network Theory could contribute to Translation Studies, Buzelin writes:

\begin{abstract}
In actor-network theory, translation refers to "the methods by which an actor enrolls others", i.e., the way in which the various actors engaged in production/innovation processes (actors whose primary interests are not necessarily the same) interpret their own objectives into each other's language so as to ensure everyone's proper participation (or the dismissal of some actors if necessary), and the continuation of the project until fulfillment. Put differently, translation evokes successive strategies of interpretation and displacement by which an idea gradually moves into becoming a scientific fact or artefact. (Buzelin, 2005, pp. 194-195)
\end{abstract}

If we bring together Latour's (2005) definition of the Actor-Network Theory, and Buzelin's reading thereof, the theory comprises of "human and non-human actors," or simply, "anything that can induce, whether intentionally or not, an action" (Buzelin, 2005, p. 197). It is when individual subjective-objectivities freely associate around a common object. The comprehension of that convergence can name or be named a theory (or method) of its own. In a literary production context (creative or transcreative) it may, internally, refer to any sign or specific word that can induce a different reading/ interpretation of another lexeme, paragraph or text. This includes the entire production process starting from the observation/idealization of the object to the textualization and the production stage by the subject. It is a circular process that can be visualized in the following graphic:

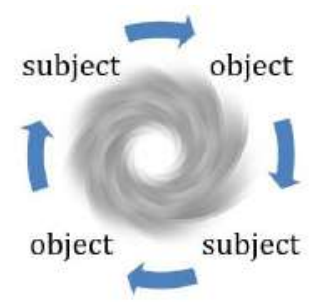

Figure 1. Circular process from subject to object. Developed by the author.
In this process, none of the two actors is stable. They inform (on) each other. I shall from now on refer to this cycle as n'zassa. N'zassa practice raises awareness of the semantic path a word may externally take as it helps provide and map the diffused meaning/interpretation particles spread all over the community of interpretation (transreaders ${ }^{2}$ ).

Unlike Actor-networks which "can only reveal themselves when activated" (Buzelin, 2005), n'zassa Meaning Weavers (Mws) may impose themselves right from the first contact with the material being studied. More than focusing on the hybridity of the product, one is fascinated by the hybrid nature of the proper subject. I must specify that the Mw, or transreaders, concept, does not concern only writers (authors), but may include, at different levels, the same parties as those convoked by Actor-Network Theory. As a result, the described scene itself may read, be read and suggest some reading-comprehension lines to the translator. In this context, the line between a *hermeneutic approach (which focuses on text and considers translation to be a process of meaning transfer ${ }^{3}$ ), and a *sociological approach (which focuses on agents and sees translation as a social process), is hardly definable for a text's comprehension. In this case, apprehension may call upon society, which is formed by peoples and their customs. Similarly, transreaders' understanding may highly depend on their capacity to get through the text's code of deantology. ${ }^{4}$ By deantology, I mean a set of duties and/or burdens that may be be-

2 "Transreaders" are readers to whom the very nature of the text imposes a reading-translation exercise. As a result, they also become future Meaning Weavers, and their reading activity includes overt translation stages.

3 Both approaches are borrowed from Johan Heilbron and Gisèle Sapiro (2002) cited in Buzelin (2005, pp. 210-211).

4 Which is different from "deontology." 
stowed on a transreader, which are controlled by the inherent codes of the text under consideration. In other words, this is a contract between the source text and the transreader.

To affirm that translation has always been present in Africa, prior to any contact with Western Explorers and colonization is definitely not an optical illusion, nor a mere perception. Every group of people that has contact of any kind with another group of people of a different language, or belonging to an alien culture and space, may somewhat naturally, if not compulsorily, necessitate some sort of mediation. Likewise, linguistic pluralism is an undeniable historical fact in Africa. States' internal compositions (like 17th $\mathrm{Akan}^{5}$ ) and social interactions - in particular, trade and the spirit of conquest - did not start either with contact with Europeans, nor did they derive from Arabs who preceded them. Such contexts, therefore, exposed those local linguistic communities to some pragmatic issues. According to Bandia, the mixing of cultures and languages in itself presupposes translation (2000, p. 360), or intra and inter mediations.

In this case, one is dealing with mediations which, beyond political and economic aspects, also included imaginary(ies) and literatures. From a pragmalinguistic standpoint, the term "imaginaries" is crucial because speech communities develop, or tend to develop distinct communication strategies fed with culture-specific items anchored in the social discourse that surrounds them. In these communication exchanges,

literary translation and reception mutually influence each other. The former makes the book available

5 See the interview with professor Pierre Ekanza available at IvoireSoir "Toute l'histoire des Agni racontée par le Pr. Simon Pierre Ekanza” (2018). in the reader's language and the latter may cause a much more profound interest for a literature and give way to future translations. (Kamgang, 2012, p. 62$)^{6}$

Thus, for decolonization to take place, one must beigin narrowing down the one-way translation activity. Otherwise, multiculturalism will mean no more than "exclusion." All it takes is the will to move forward, and to have a perception accurate enough to anticipate the geopolitics from which the internal politics of contemporary literary texts (deantology) seem not to escape. All written or rewritten literary texts from every geographical region do not seem, in my opinion, to claim more than a possibility, be it local (the writer having a dialogue with his contemporaries, or with his community of readers) or international (the writer, by means of his translator, having an exchange with other writers, readers and with the world).

Indeed, the suffocating label that condemned some "relational and marginal literary" productions (Bernd, 1987) influences that possibility and jeopardizes the circulation of ideas (mainly those from the South) within our common universal literary heritage. Manuel Rui Monteiro gives us a beautiful concatenation of that diagnostic:

May the ports of the world

Be the ports of the entire world. (Monteiro, 1987, $\mathrm{s} / \mathrm{p})^{7}$

6 "la traduction et la réception de la littérature s'influencent mutuellement. La première rend l'œuvre accessible dans la langue du lecteur et la seconde peut susciter un intérêt encore plus marqué pour une littérature et donner lieu à d'autres traductions.” All translations are mine, unless otherwise indicated.

7 "Que os portos do mundo / Sejam portos de todo o mundo." See Monteiro. 
Prior to this crucial utopia, one can observe that there is an attempt in both Actor-Network Theory and n'zassa to move towards it. Although they may have recourse to slightly different elements, their focus includes the production of a comprehensive product friendly to the parties involved. In next section, I shall try to show how such dialogue and open exchange help address the issue of multitext already mentioned above.

\section{Dialogic approach to translation}

As mentioned above, Post-colonial writers as performers of collective expressions end up concatenating multiple discourses which Bakhtin (1978) called "multiplicity of voices." This array of voices is, in Confiant's (2000) terms, a sort of multiple-texts which might impose for its translation, if not a multiplicity of transreaders, at least, a multiple target text. By grounding his work in the n'zassa philosophy, the Ivorian writer Jean-Marie Adiaffi inscribes and transmits that consciousness where the vision and the structure of the Anyi language and culture erupt in the now Europhone African narrative. According to Kamgang (2012), "if the meaning of a book [signification] resides in its literary impact, the form [signifier] produces semantic contents ${ }^{8}$ as well," i.e., giving it a sort of transnational belonging. Adiaffi's writing defies the rules of "the" original as it imposes onto the act of reading and, consequently, that of translating, a four-handed exercise-in a nutshell, a dialogic one.

More recently, in her $O$ paradigma da descrição na tradução etnográfica: Lévi-Strauss tradutor em Tristes Tropiques (2014), Ferreira laid out four

8 "Si le sens d'une œuvre réside dans sa portée littéraire, la forme engendre elle aussi des contenus sémantiques." (Kamgang, op.cit., p. 60. Notes in square brackets are my own additions). practical strategies of an ethnographic approach which prove useful in the inscription (within the target text) of the outcomes of that dialogic exercise. These are: 1) Definition: this is considered to be a closed description. It designates the attribution of a limit, of an end (de-fine), to an object/subject. 2) Explication: this can be defined as the response to questions like why, which relate to pragmatic, semantic and syntactic aspects. 3) Hyperonym: this is a meaning relation between the signified and the signifier based on hierarchical classification of the described elements. It comes into play in cases such as names of animals and natural elements (including biomass, specific types of vegetation). And, 4) Literal translation: also referred to as an anthropolinguistic description, it builds on a world view. Beyond its interlingual feature, literal translation causes estrangement as it seeks to remain closer to the piece of world represented by the source language/culture, letting the translated language erupt within the translating language.

Even though these strategies are not alien to professional ethnographers, Ferreira's interest was, in fact, a rupture of the gaze which Lévi-Strauss experienced during his 1930 trip to Brazil (where he visited several Native tribes and communities). Ferreira focused on Lévi-Strauss's self-questioning of his authority, perception and judgment of others' cosmology. The 1955 publication of Triste Tropique impacted ethnography as a whole, or at least, the French one. This shift in perception and posture newly reinforces the challenges any description of someone else's culture may present. And translation does not differ much from that. If Brazilian Native cultures were not Lévi-Strauss's research object, but he himself the subject of gaze, Ferreira writes: "how do we learn from an object which keeps shifting as we stare at it? What does the gaze do to the object when it looks, observes, examines, de- 
scribes and translates it?" In other words, what does the translator do to the other's discourse while translating it? As a result, it becomes fundamental for the translator, when it comes to literature, to have recourse to these $\mathrm{MW}$ or sparse communities of the source language/ culture during the reconstruction, in the target language/culture, of that other's discourse.

If we can consider translation to be a perpetual search for a possibility, dialogic translation consists of waging with the other, be they present physically or virtually (and/or metaphysically), the battle for meaning. Translation is, therefore, a socialization activity which opens into multiple possibilities. Instead of remaining stuck in the notion of equivalent or text readability, Bandia (2003) points out that Translation Studies would gain more if they investigated the impact a translation has on a colonized culture (source or target), and the consequences for the colonizing or homogenizing dominant language/culture (129). ${ }^{9}$ That means to try and live the portrayed experience within and outside the text, which consists of diving into the text to find out the other text it carries. The meaning of the text here is influenced by the quality of that incessant migration flux.

As a migration act and as a quest for possibility(ies), translation may require interactions which imply unpredictable events, where it is assumed that the other would be received and recognized with/in their otherness. In $\mathrm{Ri}$ card's words,

The phenomenon of translation is, in the African case, characterized by exchange, undoubtedly unfair, but nevertheless a creator of meaning; it is what I call dialogic translation. The shift to the written form of the language is constructed during the

9 As it is the case of Europhone African Literature. dialogue between translator and speaker. (Ricard, 2011, p. 14) $)^{10}$

This exchange is a fundamental act that promotes the possibility of the expected possibility. Beyond the unfairness underscored by Ricard, the dialogue itself is not exempted of some ambiguity. For Ferreira (2017), such ambiguity, which is caused by the future of migration and heterogeneity as a concrete forthcoming fact, is understandable for it is simultaneously peculiar in its journey and multiple in its memory (78). Distance, time, space can be overcome, therefore-transposable since the translation project establishes both the translator's method and their priorities regarding the author's aesthetics. In this specific process, as Ricard (2011) puts it, (trans)readers are, in their role of social forces, part of the method. They are not the end (like an unshakable target to hit) but the means (acting as erratic sentient factors). An active translator (see Coltrap, fig. 2) could undeniably reinforce their control over most of the unthought-of cultural shocks, if they are aware of the dynamic forces moving from the inside to the outside, and vice versa. This awareness is likely to help reduce translation flaws and guarantee, as far as Adiaffi is concerned, the phonological power of the Anyi language in the building of his n'zassa writing aesthetics, while preserving the text's quality or truthfulness (Grice, 1989). As Buzelin puts it,

translation and ethnographic practices, when considered from a reflexive perspective, do not meet only at the writing level. If translators do not do "field work", they gather material, they inform themselves,

10 «Le phénomène de la traduction est, dans le cas africain, caractérisé par l'échange, certes inégal, mais néanmoins créateur de sens ; c'est ce que j'appelle la traduction dialogique. Le passage à l'écrit de la langue se construit dans le moment du dialogue entre traducteur et locuteurs.» (Ricard, 2011, p. 14). 
consult sources and do research. By driving us away from the literary and textual paradigm which [...] continues to encumber translation studies and calls upon us to rather think of translation as a production process, the reflections of anthropologists help approach the notions of the "translating subject" from a new perspective. (Buzelin, 2004, p. 732) ${ }^{11}$

Translation activity, by its very nature, has always been marked by either a direct dialogism (the transreader having immediate recourse to a specialist or informant), or a distant dialogism (the transreader exchanging with a translation peer, a lexicographer or a researcher whose works help them elucidate muddy points and complex terms that arise during the translation process) that is interested in the quantity of information (Grice, 1989, p. 26). Such dialogue happens quite simultaneously between the author and the (trans)reader 1, between the translator and the author, between the translator and the (trans)reader 2 and, finally, between the author and the (trans)reader 2 . This multiple mediation, represented in figure 2 , is part of cultural translation that takes the public inside a distant mode of living. Such a "cultural" translator may intervene (Wolf, 2000) and even manipulate the translated text, in a 'friendly' way, taking into account both the context of reception and the outcomes of the dialogue (in search of the manner). I am hinting, here, at the readability, from a linguistic viewpoint, of the cultural marks of the source text. It does not imply therefore that the trans-

11 "Envisagées dans une perspective réflexive, les pratiques traductive et ethnographique ne se recoupent pas uniquement sur le plan de l'écriture. Si les traducteurs n'effectuent pas de "terrain », ils se documentent, se renseignent, consultent des sources, effectuent des recherches. En ce qu'elle nous éloigne du paradigme littéraire et textuel qui $[. .$.$] continue de grever les études en$ traduction, et nous invite plutôt à penser la traduction comme un processus de production, la réflexion des anthropologues permet d'aborder les notions de « sujet traduisant» sous un angle nouveau." (Buzelin, 2004, p. 732). lator will compulsorily adopt any specific standard or structure from the horizon of expectation. In Buzelin's view, this dialectic epistemology re-allocates in the field of translatology, a slightly different dialogism. She says:

It concerns only the second part of the process: the writing. The interpersonal exchange that was inherent to it (at least in ethnography) is taken away. It is no longer a dialogue between people, but rather a dialogue between a reader and their text, indeed, between two texts. (Buzelin, 2004, pp. 737-738) ${ }^{12}$

The dialogue between reader and text, or between texts, opens up a promising perspective. As dialogism may cause or result in mutual fecundations, each text is likely to bear the genetic imprint of that encounter. The linguistic features of "one" will become visible in the "other." Language A will speak (or express itself) within language B. Each text, in the reader's mind becomes, to some extent, semi-stranger, semi-native, semi-original and semi-translation.

If, during the period of independence (19501970) the literature in most African countries could not be considered a total rupture with former colonizers, it showed undeniable signs of transition (Kourouma, 1968, 1970; Achebe, 1952, 1953, 1958, 1960, 1964, 1966; Adiaffi, 1969 , to name but a few). The stylistic tools and cultural artifacts these writers explored (unwillingly) served as powerful ego challengers. Through styles such as these, writers would delight both the critics and readers of any kind unaccustomed to the virulence of their language, providing the latter with an un-

12 "Il ne renvoie plus qu'à la seconde partie du processus : le travail d'écriture. L'échange interpersonnel qui le sous-tendait (du moins en ethnographie) est évacué. Il ne s'agit plus d'un dialogue entre des personnes, mais d'un dialogue entre un lecteur et son texte, voire entre deux textes.” (Buzelin, 2004, pp. 737-738). 
usual pleasure. In Wolf's terms, "it is through this hybrid construction that one voice is able to unmask the other within a single discourse. It is at this point that authoritative discourse becomes undone. Authoritative discourse is univocal (2000, p. 133)." It is only out of this ego battle-which is also a mutual transmutation unthinkable in an Authoritative setting and mindset, and the ethic of reciprocity ${ }^{13}$ it implies - that one can attempt a knowledge economy.

\section{Knowledge economy: from text to dialogue}

The term "economy" should be understood as the efficient use of a resource. This effective use in literature refers to the unveiling of the ideational $^{14}$ of a metaphysic universe whose meanings reside in it being always in progress. With such a scenario, the translator should adjust to the rhythm of time. As the idealization

13 Cette dynamique bybride est aussi celle de la globalisation ou de la mondialisation. Par globalisation il faut entendre ici, non pas une uniformisation qui cristallise l'bégémonie des cultures dominantes, mais un processus qui suppose la participation de toutes les parties prenantes à l'édification d'une culture universelle. (Kamgang, 2012, p. 269) If the mutual transmutation has to occur, the needle needs to be reoriented and the world literary meridiem redefined. The virulent one-way relational instruments which perverted the concept of globalization from its very inception, must be ironed out. By doing so, perhaps, one will start to appreciate the actual value of Lang's argument. That is, globalization cuts several ways, however, implying not only the impact of world culture upon African life, or increased knowledge of world culture by Africans, but also world culture as partly constituted by African cultures (2003, p. 514). Both Kamgang's position and Lang's forecast a context wherein Brisset believes that, il ne serait plus question d'aliénation culturelle, mais d'un processus de transculturation mutuelle, d'une éthique de la réciprocité (2003, p. 69). In other words, this is only where the loose term of "culture universelle" begins to make sense.

14 Coulthard (1987) cited by Costa (2005). of the world cannot escape social and subjective influences, the n'zassa approach to translation appears to be an initiation journey. It is in this transcendental mindset that the translator follows or strives to explore the writing process, in order to get to the author and grasp his philosophy. In Souza's terms,

Thus, hardly transportable linguistic facts like the line that marks the border between foreign speech and one's own may be reported. It includes marking the difference which, in an allusive way of saying, presents itself accordingly and hinders the writing fluency that moves from the other's language to one's own. (Souza, 2014, p. 23) ${ }^{15}$

When it comes to Adiaffi's literary and artistic production, the linguistic facts which Souza (2014) referred to become omnipresent. They are almost everywhere in the text, on every page. Those elements in local Ivorian languages (most of the time proper names, onomatopoeias, riddles and/or proverbs) carry, oftentimes, micro-stories which, if carefully analyzed, can reveal unprecedented, quirky microsystems. In this type of geography full of microsystems, the reader-citizen would be subject to a set of prerogatives spread all over the text (from metaphysics to physics, from idea to subject matter - text-from author to offer, from specific source to a specified target, from sender to receiver, etc.). This dynamic and each of its inherent protocols constitute translation acts. Thus, to highlight the crucial nature of the transporter, in this case the translator, is to be aware not only of the vital importance of the text's deantology but

15 "Assim é que se pode reportar os fatos linguísticos de difícil passagem como o traço que desenha a fronteira entre a fala estrangeira e a própria. Trata-se da marcação da diferença que, sob uma maneira alusiva de dizer, se mostra enquanto tal perturbando a fluência da escritura que transita da língua do outro para a própria." (Souza, 2014, p. 23) 
also of its relationships with the outside. The consideration of the latter, as far as African literature is concerned, continuously transforms the well-known binary approach into a multiple (now equal?) mediation process. In other words, the translator's approach to each side, whatever the culture, should be equanimity-governed. For,

literature depends on being read in a certain way in order to be effective and successful. It is written for an audience, and that audience is implied in the text. Reception, response, and interpretation are in a sense preordained by the rhetoric of the literary work, but the audience also plays a role in shaping how the work will be understood and what meanings it will have. Each new generation and each new group of readers in a new setting brings to a work different codes for understanding it. (Rikvin \& Ryan, 2004, p. 128)

From that perspective, the text's deantology appears to be, directly or indirectly, the condition sine qua non to understand its structure and enjoy its meaning and flavor. The conjuncture that the literary text imposed, sometimes as both the means and the end, mostly conditions its reception and interpretation. However, both the reception and the interpretation are governed by a dialogistic precept by which the audience also plays a role in shaping how the work will be understood and what meanings it will have. Figure 2 provides a recap of the way in which many translators operate today and how a n'zassa dialogic approach may require them to operate (see below).

When Kamgang (2012) defends that the translator's engagement may equal that of the author from whom they get their power of agency, it is because an engaged post-colonial translator is not only aware of the asymmetrical power relations crystallized by colonial narratives, but most importantly, they add their efforts to the author's in order to deconstruct those forces. Their ideological positioning is what provides them with the required apparatus to effect change in the receiving target culture. Here, specifically, the notion of ethics might go through some profound turbulence, or, at least, be somewhat relativized. Though it is important to insist that not all post-colonial translation cases are activism-related, there is no doubt that in the case portrayed by the Coltrap, ethical values may need to be redefined according to the translation's intent (see Aubert, 1993). What one sees in the Coltrap is far from the merely curious action of an individual. Rather, one perceives a translator investing time and effort in understanding their personal enchantment (Baioc-

\section{Towards a collaborative translation approach}

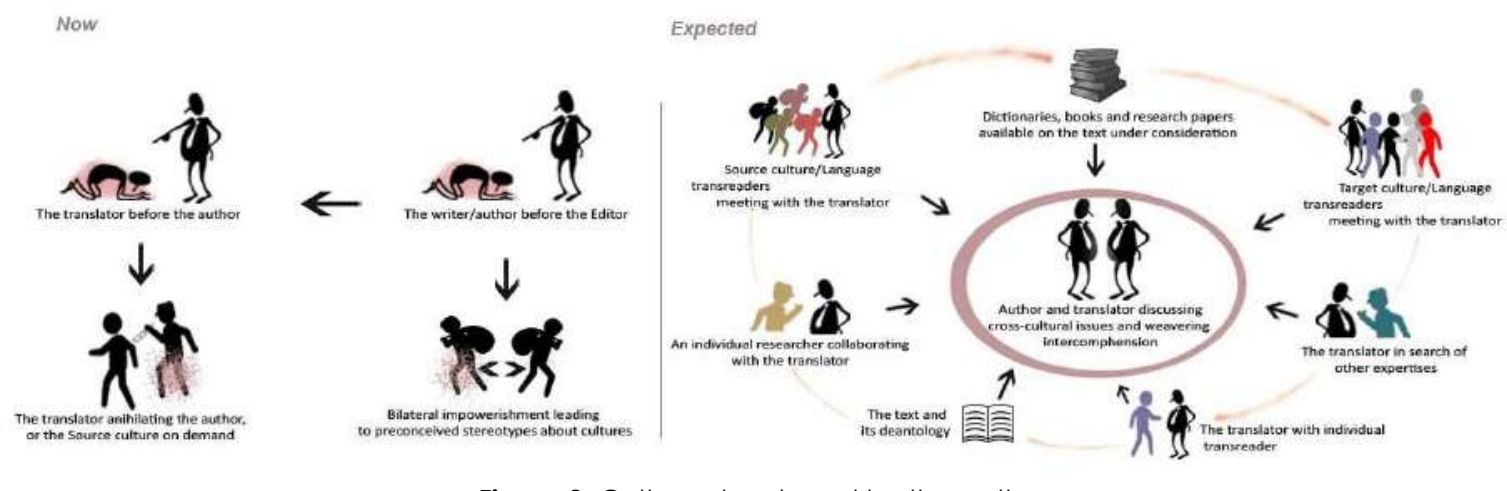

Figure 2. Coltrap developed by the author. 
chi et al., 2013) before the text under consideration. In figure 2, the "Expected" does exist in the "Now," though annihilated by the gradual forces ambushed in the process. Therefore, it is my wish that the "Expected" side be placed at the core of the practice. This performativity which should be natural to every translator recalls Ferreira's (2014) observations on LéviStrauss. The latter, with great responsibility, would reflect on the worlds he was enacting. This new approach to knowledge production transforms it into an actor-network insofar as it is itself a compositional entity (Baiocchi et al., 2013, p. 337) - that built by an individual writer/translator/ethnographer by means of a methodological gathering of souvenirs. It seems that the core point of all of this process is in fact memory. If so, Derive points out that

the closure of the writing world has instilled a set of illusions about the literary creation which determines, in a profound way, the criteria of analysis in that domain. Several slants from contemporary critique led to the re-discussion of some of these a priori that had, up to now, influenced the textual approach, because of an implicit issue - stemming directly from the writing practice - according to which the author-writer would be the unique source of meaning of his discourse. Therefore, awareness has been constantly raised, over the past few decades, on the limitations and risks of the "intentional" analysis which consists of seeking within a text "what the author wanted to say". This approach was combated by Humanities that proved that the author's consciousness could only constitute a very problematic reference for the study of the meaning of his discourse. The sociological perspective has demonstrated that the author is predetermined in his expressive functions by an ideological bias (ideas from the group to which he belongs: patterns of signified) and by a discursive function (language of the group he belongs to: patterns of signifier). Beyond that fact, both the psychoanalysis and structural sciences of language and signs insisted on the fact that the author did not have total control of his discourse: on the one hand, he might write things he has no awareness of, and on the other hand, the semantic potentiality of his text goes beyond his own intention. (Derive, 2015, pp. 66-67; my emphasis in italics) ${ }^{16}$

Paying some attention to the segments in italics starting from the discourse meaning and the author's ideological kinship to the discursive function (within which Post-Colonial writers used to weave new discourses based on an idea of "clandestinity" vis-à-vis the West), one notes that the authors themselves are never the center of attention. "The author did not have total control of his discourse," they do not have full awareness of it and "the semantic potentiality of his text goes beyond his own intention." In view of this, one can assume that a text's meaning(s) is spread over the community of readers and scholars who,

16 "o fechamento no mundo da escrita produziu certo número de ilusões sobre a criação literária que determinaram fortemente as modalidades de análise nesse domínio. Várias tendências da crítica contemporânea levaram à rediscussão de alguns desses a priori que tinham até aqui pesado sobre a abordagem textual, em consequência de uma problemática implícita - diretamente resultante da prática de escrita - segundo a qual o autor-escritor seria a única fonte do sentido de seu discurso. Assim é que muito se insistiu, nessas últimas décadas, sobre os limites e os perigos da análise 'intencional' que consiste em procurar em um texto 'o que o autor quis dizer'. Tal ponto de vista foi combatido pelas ciências humanas que colocaram em evidência que a consciência do autor só podia constituir uma referência muito problemática para o estudo do sentido de seu discurso. A abordagem sociológica mostrou que o escritor era previamente determinado em suas funções expressivas por uma formação ideológica (ideias do grupo ao qual ele pertence: modelos de significado) e por uma função discursiva (língua do grupo ao qual ele pertence: modelos de significante). Além disso, tanto a psicanálise, como as ciências estruturais da linguagem e dos signos insistiram sobre o fato de que o autor não dominava a totalidade de seu discurso: de um lado, ele ali inscreve coisas sem ter consciência delas, de outro, a potencialidade semântica de seu texto ultrapassa sua própria intenção.” (Derive, 2015, pp. 66-67). 
consequently, turn into a community of informants for the translator. By this I mean that the translator must be a memory-hunter. The discourse produced, Wolf says,

should result from a reciprocal, joint, dialogic process. Ideally, the product should be a "polyphonic text", or as Tyler puts it: "A post-modern ethnography is a cooperatively evolved text consisting of fragments of discourse intended to evoke in the minds of both reader and writer an emergent fantasy of a possible world of commonsense reality" ([Tyler], 1986). (Wolf, 2000, p. 131)

It is in these dispersed reading-receptions (the community of transreaders) that intertexts reside (in Riffaterre's sense, which is "the totality of texts that may be related to the text being considered") ${ }^{17}$ and the author's possible micro-intentions, which prove useful for the effective exploration of the text under study. Such dialogism is the undeniable principle of a true and effective economy of textual meanings, and it can pave the way for new directions to emerge. Wolf continues:

Translation between two different cultures (e.g., Northern and Southern hemisphere societies) ideally consists in mutual, dialogical production of a discourse. Such discourse can be regarded as the result of the meeting of two cultures, which merge or "hybridize" without giving up or neglecting their own specific cultural features, but which emphasize, rather, the various perspectives that converge in the translation product. (Wolf, 2000, p. 131)

In the current state of affairs, this meeting is more inclined to save the reader (and owner of the capital) from remembering their inability to master the original and to negotiate the untranslatable aspects ${ }^{18}$ of the unfamiliar idiom. More than deleting in the target language

17 See Wolf (2000).

18 Gikandi (1991, p. 167). every single trace of the other, the latter is stared at from afar and/or contemplated in a sort of "replay." For Gikandi (1991), this type of practice strengthens the power of one language over another and, consequently, acquits speakers of the powerful (dominant) language from the duty of learning the less powerful (minorized) language. ${ }^{19}$ That is to say that

Based on this compressed survey of colonial inscription, it can be said that colonial projection of African literature was essentially couched in a hegemonic discourse, which failed to account fully for the African subject it was constructing. This agen$\mathrm{da}$ of hegemony can inform research in translation studies which seeks to explore the power differential of imperialism. (Bandia, 2000, pp. 356-357)

In other words, it means assimilating foreign literary texts too forcefully to dominant values at home, erasing the sense of foreignness that was likely to have invited translation in the first place. ${ }^{20}$ Therefore, one should be careful not to fall into "a process in which the single voice of colonial authority undermines the operation of colonial power by inscribing and disclosing the trace of the other so that it reveals itself as double-voiced" (Young, 1995, p. 23). ${ }^{21}$ It means that one should, in apposition to or beside the notion of "fluid text" or text fluency, be able to consider the non-fluidity of the text as an unquestionable mark of a "good translation" as well. From all perspectives, the point is that the authors of those multilingual texts are aware, to some extent, of the readers' openness and capacity to seek meaning. Let's have a look:

19 The concept of minority will have to suffer some semantic shifts as its list and features are in constant change.

20 Kundera (1988) cited in Venuti (1998, p. 5).

21 Cited in Wolf (2000, p. 134). 


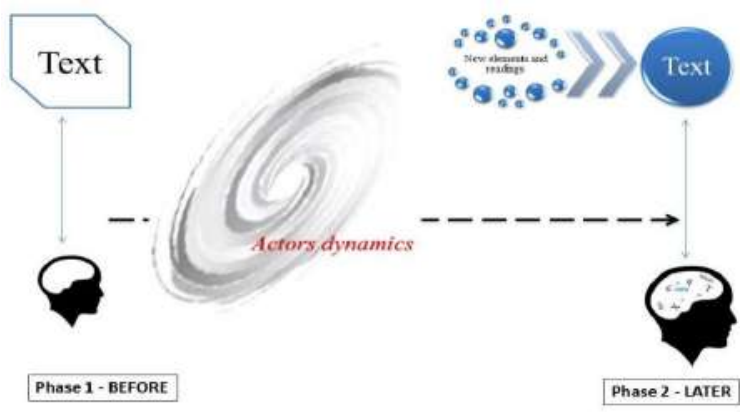

Figure 3. Object-subject in movement (developed by the author).

Is the text the same in phase 2? Is the transreader reading a different text? Or can we consider the individual reading to be the same person? Phase 2 shows with clarity that one is actually dealing with two grown actors: object (text) and transreader are no longer the same. The latter has acquired a new savvy that helps him cast a new light on the former's renewed form. Then they can discover some of the various aspects of the other until then ignored. The influence is bidirectional. Though both actors are in perpetual movement and therefore difficult to stabilize, the translator is free, using his attribution as organizer of the translation to give the product (object-text) a temporary stabilization.

If there is a dire need for the "other" to be properly represented, and even an urgency to let him represent himself, the former "other" must more than ever represent the erstwhile "self." That will enable a network of inter-subjective relationships of imageries (Aubert, 1993). For it to be profitable for Translation Studies, the translator should pay attention to four aspects: 1) how the "other" presents or introduces himself to him/her; 2) how this "other" lets themselves be represented; and 3) how in the zenith of this new fraternity the translator, moved by a genuine and laudable intention, may overstate that other's traits; and 4) how the former other (the new self) presents the onetime self (the former self, or the other self). This alertness may help escape "ethno-cultural agendas" or avoid the denial of "cultural citizenship" which Wa Thiong'o called a "Literary Identity Theft." 22 Put differently, cultural inter-comprehension depends on the price that the Post-Colonial translator (and any translator overall) is ready to pay. It is only through dialogue between subjects and forms, between divergent or convergent ideas that one may long for a real and inclusive knowledge economy.

\section{Collective Construct: A case study}

Jean-Marie Adiaffi, like many writers of his time whom I consider ethnographers manqués, ${ }^{23}$ had a spontaneous recourse to local languages, as they believed French may fail in representing African realities. Published in 1980, La carte d'identité (later translated by Brigitte Angays as The Identity Card, published by the Zimbabwe Publishing House in 1983), is full of Anyi proper names, proverbs, onomatopoeias and interjections. Next to the Anyi language cohabit in this n'zassa narrative, other Ivorian languages like Diula and Bete.

An interesting parallel that can be drawn between the practice of translators and ethnographers, as underscored by Wolf (2000), is that both are, in such a textualization process, bound by the burden of decoding what I consider to be the culture-in-the-text, which is highly dependent on the culture-of-the-text (its coding). During the re-coding process, one may be forced to establish a textualization tradition which differs from that of the existing (source and target) ones. This inasmuch as "cultural phenomena attached to belief systems could have cosmological, sociological or psycholog-

22 It transforms the source-target relationship in what I shall call the dégré zero of the translation process. (For the interview with Ngũgĩ wa Thiong'o, see N'gana, 2018) 23 See Clifford, 1998. 
ical layers of meaning" (Wolf, 2000, p. 139) and literary texts are powerful platforms for exhibiting those worlds. It is ultimately much more complicated to fit in a particular category when one considers the various contributions that MWs may provide for the elaboration of the construct (translated text).

Beyond their subversive aspects, the writing techniques designed by Post-Colonial writers are mechanisms of defense against the threat of oblivion and the experience of dispossession (see Kamgang, 2012). Both Adiaffi's ethical and political agendas end up converging and urge the translator's choices, like those of the writer himself, to becoming politico-ethical. According to Bandia (2012), the ethical dimension is not only essential but imperative when it comes to African literature. He said:

it becomes an ethical requirement, that if a reader is interested in African literature and culture, he or she should make the effort to perceive or understand African thought in its closest 'natural' form and not through a 'sifted' or watered-down version hewed to dominant domestic values or expectations. (Bandia, cited in Kamgang, 2012, p. 237)

The argument that "if a reader is interested in African literature and culture, he or she should make the effort to perceive or understand African thought in its closest 'natural' form" is not very different from Ngũgi's opinion. That is "if the reader wants to have the flavor of the original language, then they should learn the original and read the work in the original" (2018, p. 267). This must not be an avenue for misinterpretations. What these two passages tacitly recall is the unfinished nature of any translation. When one agrees that an unfinished text may oftentimes benefit, for a special purpose, from the status of a finished one; eth$i c s$ should be no more the duty and the burden of the translator alone, but a shared responsibility, including particularly transreaders.
It is worth mentioning that The Identity Card (1983) contains around 92 terms (names and expressions) in local languages. But considering the limited space, I chose to discuss the translation of only two proper names: Mélédouman and Floco-Guard Gnamien Pli.

\subsection{Do we translate Mélédouman?}

The Identity Card (1983) is the story of Mélédouman, prince of Bettié, who lived in a time when his city was still a French colonial Circle. One day, Prince Mélédouman is arrested at home and taken to the Circle for no apparent reason by Commandant Kakatika Lapine (official representative of the French colonial Administration in Bettié) and his Floco-Guard Gnamien Pli. As the Commandant asks for Mélédouman's identity card, a harsh debate begins between the two men about what the notion of identity itself stands for. In response to what he considered to be a contemptible and intolerable questioning of his Administration and of his own authority, Commandant Kakatika reacts by saying: "Guards! Take him to the truth-cell. And bring him to reason. This argumentative idiot, this rebel of a nigger, may have been innocent but he certainly isn't any longer" (1983, p. 32). After a seven-day torture, Mélédouman loses his eyesight. It is during his judgment that he is finally told of his indictment, since before that time they had nothing to hold against him. In the midst of mistreatments and blows, his identity card had fallen out of his pocket and provided an excellent motive for the Administration to justify its ill-treatment of the prince. Two hypotheses were exploitable by the colonial Administration: a) ask the prince to provide his identity card. "If you did, it meant this one wasn't yours" (1983, p. 108); and b) "But if you didn't, it meant that our suspicion would be confirmed." This was the scheme within which Mélédouman was given seven days to provide 
his Identity Card. There he was, blind, waging a war for his very existence, one that Kakatika was clearly denying him. By the end of the seven-day-ultimatum, he went back to the Circle where, in a sort of mea culpa, commandant Kakatika said:

As soon as you left, we found your identity card. [...] Yes, Nanan. The mistake was on the part of one of my guards. He picked up your identity card somewhere and we thought that some words had been scratched off... We thought it was a case of forgery... It's a serious offence... But the name was slightly faded... That's why we asked you to produce your identity card (Adiaffi, 1983, p. 108).

Of course, Prince Mélédouman could not provide it because it was in commandant Kakatika's possession. Absorbed by his project of revisiting not only the writing canon but also the history of the Bettié people and of Côte d'Ivoire as a whole, Adiaffi played on names to show how the colonial power disregarded the existing African traditions and the mechanisms they use to identify and name one another. What Kakatika and his Administration did was to establish their own identification system, which depended on the destruction of the existing one. Adiaffi said:

The name plays on that double reality: the Black who knows he has an identity, and the latter being negated by the White. It is all in the intonation. If it is the White speaking, he has a different intonation and the name means something else. If it is Mélédouman himself speaking, it has another meaning. (Adiaffi, cited in Gallimore, 1996, p. 33) ${ }^{24}$

24 «Le nom joue sur cette double réalité : le Noir qui sait qu'il a une identité et la négation de celle-ci par le Blanc. C'est dans l'intonation. Si c'est le Blanc qui parle, il a une intonation différente et le nom veut dire autre chose. Si c'est Mélédouman lui-même qui parle, c'est autre chose» (Adiaffi, cited in Gallimore, 1996, p. 33).
In The Identity card, Adiaffi already did what Ferreira referred to as explication, i.e., "Are you Mélédouman? (meaning either I have no name or more precisely, they falsified my name.)" In fact, by offering this translation/ explication, Adiaffi provided the transreader with a first element for the meaning weaving. Each part of the explication highlights one of the reading possibilities. During the translation process to Brazilian Portuguese, I had students and participants (in academic meetings) contribute to the re-creation of the linguistic subtlety of the source text in view of maintaining the writer's agenda, clearly inscribed in his writing style. It shall be said that the Portuguese language barely allows two diacritical signs on a single word like French does. In fact, given the significance of intonation, various debates revolved around the location of the accent on the lexeme. Every intervenient (now transreader) had to substantiate their argument with a reference (be it a dictionary, an article, a déjà vu from their reading experience, etc.). Therefore, as participants got to know the translation project and understood the role of intonation, we went from a) Mele-dumã , b) Meledúman, to c) Mêledumã. We finally ended up with Meleduman with no diacritical sign. The mediation with Mws happened on two levels. On the one hand, I explored: a) Mws of the SL including native speakers, $b$ ) the hints the author himself provides within the text, c) the works available on the Anyi language and on the book under consideration. On the other hand, we have Mws of the TL who helped find, on the horizon of expectation, a place for the text-discourse that was being constructed collectively.

\subsection{What about Floco-Guard Gnamien Pli?}

Like in most colonial settings, the French Circle of Bettié had its black military men. These black people trained to serve the Ad- 
ministration were selected according to their knowledge of the local geography, languages and traditions. Floco-Guard Gnamien Pli, as it appears in the Zimbabwean translation, is a black military man whose abhorrence of his own black brothers is astonishing. He wishes to subject them all to his mercy. However, his attempts on many occasions to impress them fail, for they find him both comical and stupid. In the particular case of Floco-Guard, Adiaffi combines three of Ferreira's concepts: definition, explication and literal translation. In-text glossing is among the many strategies that Adiaffi uses to distribute the useful Mws within the text. Here is a case in point:

Suiting once more the action to the word, our floco-guard (a rather unglorious name given by Blac$\mathrm{ks}$, at the time of hard labour, to their most terrible guards, the bloodthirsty ex-conquerors in their red chechias, as cruel and merciless as cangaceiros. They were unconditionally in the district commandant's pay. Floco means he who is not circumcised, that is an idiot, a thickhead, a vile man, a rapscallion, a son of a bitch, a poor bastard who understands less than nothing. Hence the terrible, vengeful association: floco-guard). (Adiaffi, 1983, p. 4)

One realizes that Mws do not refer only to transreaders, but also include any element that carries, or helps reach and formulate, the text's implications. As implicit ANTs, MWs may perform (or help build) contexts (or be themselves contexts) that are experiential in nature. In so doing, they become virtual and ambulant labs of sorts, in which translator and transreaders carry out thousands and thousands of experiments on the possible lexical combinations. Every single meeting with a new transreader may reorganize the context or cast a new light on it.

With regard to the implementation of the strategies Ferreira (2014) listed, Adiaffi (1980) used artifices like parenthesis (), comas, or terms like means, meaning, that is, more specifically. Two fundamental aspects of the composition of the current name must be noted: 1) the invention of a portmanteau word, and 2) an ironic combination (see below):

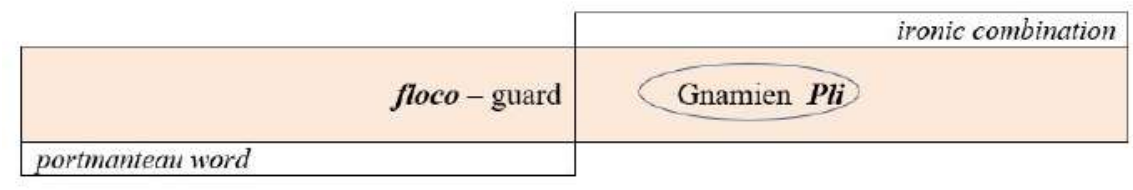

Figure 4. A n'zassa name.

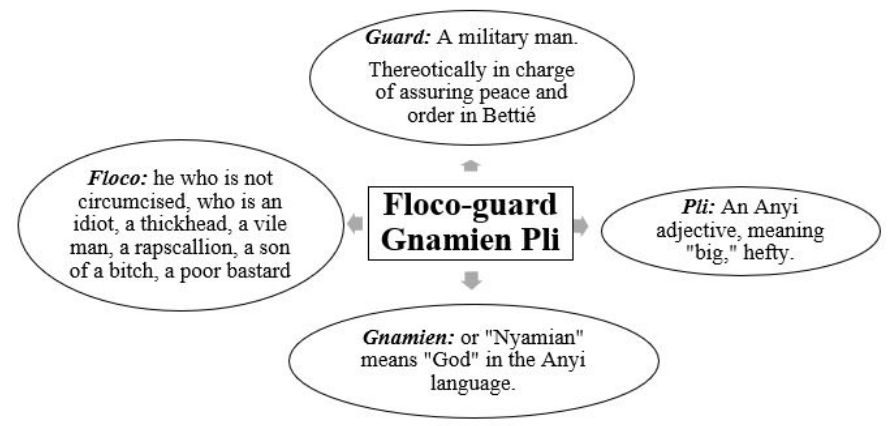

Figure 5. Based on The Identity Card (1983) by Jean-Marie Adiaffi 
Though Mélédouman and Floco-Guard are both sarcastic names, the latter presents a very interesting structure in which every particle, with its individual meaning, does not alter the anatomy of the expected image. Word order still corresponds to meaning order. It reveals exactly the various facets of Nhamien Pli (see Figure 5 above).

In the translation process to Brazilian Portuguese, I came (jointly with Mws) to use guarda for 'guard' which refers, in theory, to a military (wo)man. It is also commonly utilized in Brazil to refer to vigilante (janitor), who generally bears no relation with the army. Its association with Floco will produce a quick reaction in the reader's mind. For one moves from a man who incarnated a national treasure and represented both the law and the State, to a "vile man, a rapscallion, a son of a bitch, a poor bastard who understands less than nothing." This type of association typical to n'zassa contributes a lot to the peculiarity of Adiaffi's works. He proceeded by defining the term "floco" as he who is not circumcised, and then went on providing explications about its possible signification in the traditional district customs of Bettié.

As part of the colonial army, Floco-guard knows that he is there under the auspices of the Administration, so he wants to abuse his contemporaries and submit them to his personal caprices. As he considers himself a god, his brothers call him "Gnamien" (God) whose spelling I have adapted to Brazilian Portuguese: Nhamien. To prove to him their total adherence to the idea he has of himself, they add "Pli" (big or hefty) instead of "Kpli" (grand, mighty) to Nhamien. For example:

They gave the floco-guard the much-envied nickname of Gnamien Pli (Big God) but the little devils emphasised Pli (Big) much more than Gnamien (God). (Adiaffi, 1983, p. 7)
One crucial point where Mws proved fundamental was the translation of "floco." There exists, in Portuguese, the lexeme "floco" and it designates a "flake;" speakers generally relate it to the cotton flower. Two options could be explored: either a) we re-signify the existing word or; $b$ ) we find a stratagem that draws the reader's attention on that semantic mobility (see Bra, 2014). The final solution was to put a circumflex on the last "o" of the word: flocô. As Adiaffi did in the source text, in which the Anyi language speaks through French, this diacritical sign $\left(^{\wedge}\right)$ also helped reach the same effect: the Anyi speaks in and through Portuguese anew. Thus, I could build a construct that contemplates the traits of the parties involved. The result is guarda-flocô Nhamien Pli.

What this n'zassa translation practice recalls to me, not as a mere bystander but as an active transreader, are the four Gricean maxims: 1) quantity of information (which the translator gathers from each transreader), 2) quality or truthfulness (the confrontation of interpretations helps iron out ambiguities), 3) relevance or consistence of the context (Adiaffi's agenda of revising Bettié's history and the political and social conjuncture in which the book was produced imposed some key considerations); and 4) manner or clarity (the bringing together of cultural issues and the writing style that the author explores-submitted to the confrontation of interpretation-clearly assists the translator in his decision making). The above dialogue with students and colleagues gave both the translated text and the process itself the opportunity to be a constantly revitalized practice, which is likely to create between the parties (translator and transreaders), a type of immediate collective acceptance 


\section{Conclusion}

The experience of the text (source and target) begins with its first contact with transreaders. This is where it establishes itself and articulates its movements within the system that will be its new home, if not a shelter against oblivion. The left column of the Coltrap (fig. 2) above shows where we still are, and one perceives that the right side of the figure is generally not discussed, or simply hidden. When an individual's work is selected, that collective recognition can contribute to its the future canonization. Literary prizes are a testimony of it. Thus, as an author's work is canonized not only by editions and re-editions and, above all, by critiques; a n'zassa translation approach aims to reach that level through the effective exploration of the informants' network (Mws). Internet and online tools have transformed our relations to one another and to texts, so too should it be when it comes to carrying out translations.

In this paper, one can see that both Latour's Actor-Network Theory and the n'zassa perspective in translation bear some convergence points. Still, the resources they respectively explore may slightly differ from one another. They do not claim to be applicable theories per se, but to provoke reflections. This is why the n'zassa focuses on factors like: humans (the writer, transreaders and translator) and non-humans (the editing process, market and social realities). Besides, a good utilization of Ferreira's suggestions relies on the sound comprehension of these dynamics (see fig. 1 $\& 2$ ). For that, two fundamental points must be considered: the translator's ability to translate with and without the text, and his ability to translate the world in the text and the world of the text. This will take us to a (un)common collective "objectivity" about reality—if this exists in literature-towards which the text is calling us.

\section{Acknowledgements}

My special thanks to the Brazilian Coordination for the Improvement of Higher Education Personnel (CAPES) for the research funding, and to Mylène Otou-Mbezele and Cassiano Fagundes for their readings.

\section{References}

Adiaffi, J-M. (1980). La carte d'identité. Abidjan: Ceda.

Adiaffi, J-M. (1983). The Identity Card (B. Angays Katiyo, trad.). Harare: Zimbabwe Publishing House.

Akohoue, T. (2013). "La carte d"identité de Jean-Marie Adiaffi ou la quête identitaire à travers la symbolique de l"initiation allégorique". The Coastal Review: An Online Peer-reviewed Journal, 4(1). DoI: 10.20429/ cr.2013.040104

Aubert, F. H. (1993). As (in)fidelidades da tradução. Servidões e autonomia do tradutor. São Paulo: Editora da UNICAMP.

Baiocchi, G.; Graizbord, D. \& Rodríguez-Muñiz, M. (2013). Actor-Network Theory and the ethnographic imagination: An exercise in translation. Qualitative Sociololy, 36(4), 323-341. DoI: 10.1007/s11133013-9261-9

Bakhtin, M. (1978). Esthétique et théorie du roman (D. Olivier, trad.). Paris: Édition Gallimard.

Bandia, P. F. (2000). Towards a history of translation in a (post)-colonial context: an African perspective. In A. Chesterman, N. Gallardo San Salvador and Y. Gambier (Eds.), Translation in Context. Selected contributions from the EST congress, Granada 1998 (pp. 353-362). Dor: 10.1075/btl.39.39ban 
Bandia, P. F. (2003). Postcolonialism and translation: the dialectic between theory and practice. Linguistica Antverpiensia, New Series - Themes in Translation Studies, 2, 129-142. Retrieved from https://lanstts.uantwerpen.be/index.php/LANS-TTS/ article/view/81/36

Bernd, Z. (1987). Negritude e Literatura na América Latina. Porto Alegre: Editora Mercado Aberto.

Bra, B. (2014). Mobilité discursive des lexèmes et constructions phraséologiques en langue agni dans les romans de Jean-Marie Adiaffi. Revue Electronique Internationale de Science du langage, sudLangues, (22).

Bra, B. (2016). Prosody and N'zassa Writing Style in Jean-Marie Adiaffi's Novels. US-China Foreign Language, 14(3), 227-238. DOI: $10.17265 / 1539-8080 / 2016.03 .006$

Bra, B. (2017). Le n'zassa discursive et ses procédés de creation. Revue de l'ILA: Cahiers Ivoiriens de Recherche Linguistique, (42), 72-83.

Brisset, A. (2003), "Alterity in Translation: An Overview of Theories and Practices", in S. Petrilli (ed.), Translation, Translation (pp.102-132). Amsterdam, Rodopi.

Buzelin, H. (2004). La traductologie, l'ethnographie et la production des connaissances. Meta, 49(4), 729-746. DOI: https:// doi.org/10.7202/009778ar

Buzelin, H. (2005). Unexpected Allies. How Latour's Network Theory Could Complement Bourdieusian Analyses in Translation Studies. The Translator, 11(2), 193-218. Retrieved from https://www. tandfonline.com/doi/abs/10.1080/1355 6509.2005.10799198

Clifford, J. (1998). A experiência etnográfica: antropologia e literatura no século $X X$. Rio de Janeiro: Editora UFRJ.

Confiant, R. (2000). Traduire la littérature en situation de diglossie. Palimpsestes, 12. DOI: 10.4000/palimpsestes. 1635
Costa, W. (2005). O texto traduzido como re-textualização. Cadernos de Tradução, 2(16), 25-54. DOI: https://doi.org/10.50 $07 / \% 25 \mathrm{x}$

Derive, J. (2015). Literarização da oralidade, oralização da literatura. (A. Sobreira, F. Veloso et al., trads.). Belo Horizonte: FALE/UFMG.

Ferreira, A.M de A. (2014). O paradigma da descrição na tradução etnográfica: Levi-Strauss tradutor em Tristes Tropiques. Acta Scientiarum. Language and Culture, 36(4), 383-393. DOI: 10.4025/actascilangcult.v36i4.23837

Ferreira, A.M de A. (2017). Traduzir À Petites Pierres de Gustave Akakpo: a escrita heterogênea e a questão dos provérbios. Cadernos de Tradução, 37(3), 71-91. DOI: https://doi.org/10.5007/2175-7968.201 7v37n3p71

Gallimore, R. B. (1996). L'oeuvre Romanesque de Jean-Marie Adiaffi. Le mariage du mythe et de l'histoire: fondement d'un récit pluriel. Paris: L'Harmattan.

Gikandi, S. (1991). The Epistemology of Translation: Ngũgĩ, Matigari, and the Politics of Language. Indiana University Press: Research in African Literatures, 22(4), 161-167.

Grice, P. (1989). Studies in the Way of Words. Cambridge: Harvard University Press.

Ivoiresoir. (2018, April 30). Toute 1'histoire des Agni racontée par le Pr. Simon Pierre Ekanza. In YECLO. Retrieved from https:// www.ivoiresoir.net/toute-histoire-des-agni-racontee-par-pr-simon-pierre-ekanza/, on 07.01.2019.

Kamgang, E. (2012). Discours postcolonial et traduction de la littérature africaine subsaharienne après les années soixante: Rémanences colonialistes [Thesis]. Ottawa: Ecole de Traduction et d'Interprétation.

Lang, G. (2003), "African Literatures in the Year 2050", in M. S. Smith (ed.), Globali- 
zing Africa (pp. 511-516). Trenton, NJ, Africa World Press.

Latour, B. (2005). Reassembling the Social - An Introduction to Actor-Network-Theory. New York: Oxford University Press.

Latour, B. (2008). Reensamblar lo social. Una introducción a la teoría del actor-red (G. Zadunaisky, trad., $1^{\text {st }}$ ed.). Buenos Aires: Manantial.

Monteiro, M.R. (1987). Eu e o outro - o invasor ou em poucas três linhas uma maneira de pensar o texto. In C. Medina, Sonha, mamana África. São Paulo: epopeia.

N'gana, Y. (2018). Entrevista com Ngũgĩ Wa Thiong'o. Cadernos de Tradução, 38(1), 261-268. Retrieved from https://periodicos.ufsc.br/index.php/traducao/article/ view/2175-7968.2018v38n1p261

Ricard, A. (2011). Le sable de Babel, traduction et apartheid: esquisse d"une anthropologie de la textualité. Paris: cNRs Editions.
Rikvin, J. \& Ryan, M. (Eds.). (2004). Literary Theory: An Anthology (2 ${ }^{\text {nd }}$ ed.). Oxford: Blackwell.

539

Souza, P. de. (2014). De como se perder na tradução. In A. Guerini \& W. C. Costa (Org.), Sobre discurso e tradução (pp. 13-26). Florianópolis: PGET/UFSC.

Tro Deho, R. (2009). La littérature orale et la rhétorique du mensonge dans "Silence, on développe " de Jean-Marie Adiaffi. TRANS, 7. DOI: $10.4000 /$ trans. 296

Venuti, L. (1998). The scandals of Translation. Towards an ethics of difference. London and New York: Routledge.

Wolf, M. (2000). The Third Space in Postcolonial Representation. In S. Simon and P. St-Pierre (Eds.), Changing the Terms. Part I. (Post)colonialism and the powers of translation (pp. 127-145). Ottawa: Les Presses de 1'Université d'Ottawa | University of Ottawa Press.

Cómo citar este artículo: N'gana, Y. (2019). N'zassa: from a collaborative translation approach to a collective construct. Mutatis Mutandis. Revista Latinoamericana de Traducción, 12(2), 519-539. DoI: 10.17533/udea.mut.v12n2a09 